\title{
Gender Bias and Sexual Harassment in the Mining Industry: Unceasing Hurdles to Females' Career Development and Work Safety
}

\section{Bias Gender dan Pelecehan Seksual di Industri Pertambangan: Hambatan Tidak Henti-Hentinya bagi Pengembangan Karir Wanita dan Keselamatan Kerja}

\author{
Karen Sarah Iradukunda ${ }^{1}$, Obed Nahayo ${ }^{2}$, Pinky Saptandari ${ }^{3}$ \\ ${ }^{1,3}$ Sekolah Pascasarjana, Faculty of Social and Political Sciences, Universitas Airlangga \\ Jl. Airlangga 4-6, Airlangga, Surabaya East Java 60286, Indonesia \\ 1,2Laterite Ltd, KG 12 Ave, Gasabo, Kigali, Rwanda
}

\begin{abstract}
Introduction: Gender issue has been tremendously discussed all over the world, and it inhibits females' career development and work safety. Nevertheless, it specifically persists in the mining industry and continues to discourage women from developing and managing their careers in the mining industry. Moreover, gender issue hampers their work safety as well in spite of the fact that researchers have estimated that around $10 \%$ of females work in the mining sector. This research aims to explain how gender bias and sexual harassment in the mining industry hamper females' career development and work safety, which in turn affects this industry's sustainable development. Methods: The method of this study was qualitative descriptive research approach, and the snowball sampling technique was used, where researchers selected 23 informants who had experienced gender bias and sexual harassment while working in mining companies. Phone interviews were conducted, and informants answered questions about gender bias and sexual harassment in the workplace towards their career development. Transcription, segmentation and conceptualization were done to analyze data. Results: The research results have shown that gender bias and sexual harassment are big stumbling blocks not only to women's career development and work safety in the mining sector but also to the industry itself. The research has revealed that the hiring process, where most women get rejected because of wrong perceptions and cultural background that mining-related works are for men, plays a big role in this issue. Moreover, those who are hired are not taken care of. Conclusion: Gender bias and sexual harassment significantly affect career development of female workers, and they also hinder their work safety and financial stability.
\end{abstract}

Keywords: career development, gender bias, mining, sexual harassment, work safety

\begin{abstract}
ABSTRAK
Pendahuluan: Masalah gender telah banyak dibahas di seluruh dunia, dan hal itu menghambat pengembangan karir dan keselamatan kerja perempuan. Namun demikian, hal tersebut secara khusus bertahan di industri pertambangan dan terus meruntuhkan perempuan dari mengembangkan dan mengelola karir mereka di pekerjaan industri pertambangan, dan hal itu juga menghambat keselamatan kerja mereka, sementara peneliti memperkirakan bahwa sekitar 10\% perempuan bekerja di sektor pertambangan. Penelitian ini menjelaskan bagaimana bias gender dan pelecehan seksual di industri pertambangan menghambat perkembangan karir dan keselamatan kerja perempuan, yang pada akhirnya mempengaruhi pembangunan berkelanjutan industri ini. Metode: Pendekatan penelitian deskriptif kualitatif digunakan, dan teknik snowball sampling digunakan, maka peneliti memilih 23 informan yang pernah mengalami bias gender dan pelecehan seksual di tempat kerja di perusahaan pertambangan. Wawancara melalui telepon dilakukan, dan informan menjawab pertanyaan tentang bias gender dan pelecehan seksual di tempat kerja terhadap pengembangan karir. Transkripsi, segmentasi dan konseptualisasi dilakukan untuk menganalisis data. Hasil: Hasil penelitian menunjukkan bahwa bias gender dan pelecehan seksual tidak hanya menjadi batu sandungan bagi pengembangan karir perempuan dan keselamatan kerja di sektor pertambangan tetapi juga bagi industri itu sendiri. Hasil penelitian mengungkapkan bahwa proses perekrutan di mana sebagian besar perempuan ditolak karena persepsi dan latar belakang budaya yang salah bahwa pekerjaan terkait pertambangan adalah untuk laki-laki memainkan peran besar dalam masalah ini dan mereka yang dipekerjakan tidak diperhatikan. Simpulan: Bias gender dan pelecehan seksual mempengaruhi secara signifikan perkembangan karir pekerja perempuan, dan juga menghambat keselamatan kerja dan stabilitas keuangan mereka.
\end{abstract}

Kata kunci: bias gender, keselamatan kerja, pelecehan seksual, pengembangan karir, pertambangan 


\section{Corresponding Author:}

Obed Nahayo

Email: obednh843@gmail.com

Telephone: +6281358803176

\section{INTRODUCTION}

In many corners of the globe, the issue of gender bias and sexual harassment has been rampant for decades and even centuries. This problem has been hindering women from advancing in many aspects, including developing their careers even from performing some types of works at their workplaces. This even makes the development of some societies or countries move slowly. Many countries, states, governments, and international organizations have fought against this issue, but still these issues are hindering females' career management and development process, which also impacts their societies' daily lives as well as their community integration and organizational sustainable development (Kurniawan et al., 2018).

Gender bias is an associate disposition or partisanship concerning one sex over the opposite. This inclination will be apprised or oblivious and should be exposed from multiple points of read, each unnoticeable and taken for granted. It has been revealed that gender bias is ambiguously defined (Kurniawan et al., 2018), and in some cases, it is also taught implicitly through the resources chosen for classroom use (Fahriany, Alek and Wekke, 2018), and in the end, it strangles females' career planning and development. As a result, this brings more sexual harassment and maltreatment of female workers at their workplaces especially in the mining sector, which happens in communities without rules and regulations protecting females (World Health Organization, 2009).

There are some cases where females are not paid the same amount of salary as their male counterparts whilst they have the same job positions, same responsibilities, and same level of education; this is called the gender pay gap. Many female job hunters get rejected when applying for mining jobs or are prohibited to work there while they have the required qualification (Botha and Cronjé, 2014). Much research has been done on gender bias, sexual harassment, but there is still a need to illuminate more in terms of career and management especially in the mining sector.

Mining sector includes the extraction of a wide scope of resources, from gold and silver to clay and salt (Jenkins, 2014), and so far only men are given high chances and opportunities to work in the mining industry because of wrong perceptions from historical background putting females behind in these job types. As of the Industry 4.0 technologies are believed to offer an opportunity to break sex inclination in business, essentially by decreasing past specialized boundaries to female passage into the labor force including that from the mining industry (Fernandez-Stark, Coutu and Bamber 2019), organizations need to wake up and stop this gender bias and give females their part in the sustainable development of mining industry.

In their research about discrimination in workplaces especially gender-related, Plickert and Serling (2017) stated that gender stereotypes and social roles seem to remain static, and gender bias and women isolation diminish satisfaction and inspiration as well as reduce responsibility and employees' degree of excitement. This also raises the stress level in the employees' daily life, which becomes a big challenge in their living style in the communities and as time goes on this becomes a driving factor to the destruction or disturbance of career development of female workers, which finally affects their social inclusion by feeling guilty of doing or not doing what is needed or not (Plickert and Sterling, 2017) stated that organizational systems, practice layouts/dimensions and also individual life situations are known to modify or build females and males' professional careers differently. It can be accepted at the meeting level that ladies' authority practices are increasingly viable from an authoritative perspective. In addition to organizational effectiveness, it has also been shown on a large scale, multi-level study that a wide scope of women at higher organizational levels is related to gender bias (Larsson and Alvinius, 2019).

Career development at work is one of the pillars of individual and organizational performance. It alludes to "the results of activities on career designs and plans as observed from both individual and organizational viewpoints." The results desired by the organizations include achieving the best match between individuals and occupations. Career development journey can be seen in three particular stages: First is staffing and direction, second is evaluation, and third is development (Cao and Thomas, 2013). Career planning that helps in successful career development is described as the move to get individual qualities, which effectively looking for the exhortation and direction of trusted companions, chiefs, and topic specialists (Schulz 
and Enslin, 2014). Employment demands as well as resources play a vital role in two procedures within the working environment, notably the energy-driven and work-driven processes. That is why the ideal execution conditions are situations where workers have modestly high-work requests and high-work assets to satisfy them (Schulz and Enslin, 2014).

Sexual harassment encompasses a wide range of actions from an oral misdemeanor to sexual abuse or attack. It can happen in a wide scope of social situations, cultures, and lifestyles, for example, the workplaces, the families, schools, place of worships, and so on. Women are sometimes forced to expend their efforts in maintaining their positions as well as developing their careers (Jáuregui and Olivos, 2018), and we should not forget that harassers or casualties/ victims might be of any sex.

Females have been struggling to overcome the bias of gender issues, but in many cases, the cultures of certain societies have been a stumbling block to this effort. In many workplaces, women have experienced many sexual harassment situations which in turn hamper their career and social welfare as well because if sexual harassment or sexual bullying happens, one might even feel more secluded and find it hard to manage life in the real world especially at the workplace (Piñeiro and Kitada, 2020). These sexual harassments that bring females to lower their self-confidence at work make them change in behaviors (Mankhi, 2020). This later on impacts their working lives and social interaction with the society. An example of this is forced or early marriages which cause health problems especially for those in gender inequality continuous experiences (Nurmala, Astutik and Devi, 2020).

An evaluation proposes that ladies involve more or less than $10 \%$ of occupations in the enormous scope of the mining industry. Gender bias and separation in recruiting rehearse play a part in this, as accomplishing work plans that meddle with family duties and cause social disconnection, making digging turn out ugly for some ladies while also it sows in men mindset that females cannot be their co-workers in the mining industry because they are unable. The incorporation of ladies in mining is difficult for the mining of work-related culture. The work cycle is still gendered, with a bigger number of men feeling comfortable than do ladies (Botha, 2016). It is recommended that for mines to prevail with regards to bringing and holding ladies, they must be all the more family-accommodating, get away from some unacceptable discernments, and take a gander at the work done not who did it.

The issues confronting the communities can likewise be found inside the mining organizations themselves. Thus, businesess should acknowledge lean, successful, and safe mining creation Abrahamsson et al. (2014), and this employs the attention to hiring female candidates in all available jobs because they can perform well as males do in this mining industry based on some testimonies. The development of the mining industry always comes with environmental, social and economic impacts that change women's lives, and gender equality is one of the impacts that require attention among stakeholders in the industry (Pimpa, 2019), based on the fact that many people consider this sector as dangerous, stressful or risky for women or females' lives. Today, even if it is often unintentional, mining companies continue to hinder females' employment in the mining sector through recruitment processes, subcontracted work, and masculine workplace policies that discourage women's career and favor men in the role of the family's main provider (Pugliese, 2020).

People question the safety of females when it comes to mining industry jobs for females, which in turn creates or strengthens gender inequality in this sector, but they do not try to find out that misbehaving of some miners can come from different perspectives. As mentioned by Cheng and Lin (2020), unsafe behavior among miners is the main cause of accidents in coal mines, which means that it has nothing to do with gender ability. Many studies have been done on gender balance and sexual harassment, but this research did not cover the mining industry particularly in Rwanda and Burundi where this research was conducted. Therefore, the objective of this research was to explain how gender bias and sexual harassment in the mining industry hamper females' career development and work safety, as well as give recommendations to eradicate this ceaseless issue.

\section{METHODS}

This research paper used a qualitative approach, which is a scientific approach of observation to gather non-numerical data. It is an easy way to gather information from informants who have worked, work, in mining industry, who also probably or likely have experienced gender bias and its consequences at work or during the work attempt in 
the mining company. This research was conducted in Rwanda and Burundi as neighboring countries whose cultures and living styles are almost the same, and the research was conducted from 2020 to 2021. The informants were working in mining industries in both countries. Moreover, due to the fact that the information needed was confidential, the researchers needed enough time to cover and collect useful information from the informants. The research was conducted under ethical clearance number 610/ UN3.1.15/PK/2021 from the research committee of Sekolah Pascasarjana, Universitas Airlangga. To select research informants, a snowball sampling technique was used, and the method used was a convenience sampling technique, which is usually used when it is difficult to access research subjects with the earmarked characteristics (Naderifar, Goli and Ghaljaie, 2017).

By using the above sampling technique, the existing research subjects recruited future subjects among their close acquaintances, and this was applied during this research wherein the researchers could be referred by the informant to the next informants who was found to have experienced gender bias or sexual harassment in a certain mining company. Twenty-three female informants were selected to participate in this research $(n=23), 13$ informants from the mining industry in Rwanda and 10 informants from Burundi, some of whom had not joined themining industry. Afterwards, they were given IDs where informants from Rwanda were given IDs with the form of RI1 to RI13 and Burundian informants were given IDs in the form of BI1 to BI10. The researchers used in-depth interviews with selected informants to collect primary data for the research, and all the data were collected from the women only.

All informants were female workers and frontliners in the mining industry and others who were rejected or failed to join the mining industry due to their gender or gender bias from the workplaces where they wanted to be employed. The authors recruited two potential subjects at first, and then snowball sampling was used on subsequent subjects based on the fact that they could have experienced gender bias or sexual harassment at work. Informants were asked their opinions about gender bias and sexual harassment at work as well as questions about their experience with the issue and how that could have affected their career development.

Interview guide was composed of a total of 10 questions, 5 of which asked about gender bias and sexual harassment at work, and 5 of which asked about career development and work safety. Interviews were done through phone calls because it was hard to reach every informant directly, and the results of the interview were recorded and transcribed in the end in order to conduct further analysis. Finally, content analysis was used (Erlingsson and Brysiewicz, 2017) to analyze data and make conclusion from what informants had said.

After a long time of carrying out interviews which were taking approximately 1 hour each; transcription, segmentation and conceptualization were conducted to analyse the data, then the research came up with the research data analysis to explore and explain how gender bias and sexual harassment impede female career development and management in the mining industry, which in the end also interferes in the sustainable development of the industry in general. Data analysis was done using Maxqda software which was used in qualitative data analysis, and triangulation was also carried out to confirm the credibility and validity of data collected.

\section{RESULTS}

Research results represent all data, test results, laboratory records, technology, technical knowledge, and any other information obtained during the implementation of the research project. Research results refer to all data and information generated during the conduct of sponsored research during the term of this agreement. In this research, informants have provided their opinions, experiences and ideas regarding gender bias and sexual harassment in the workplace that hamper their career development.

"In my higher education, I studied mining engineering as my field of study, but when I applied for a job, they didn't consider my degree first, yet they instead started asking me if I could do it or really needed the job, which was commonly regarded as a man's job. Not even just me. Some of my friends also experienced the same. That is insane! I have spent a lot of time learning and studying about mines and minerals as well as natural resources. Why shouldn't I perform any job related to it if given a chance? It's not a long time ago since I graduated, but I have hope that soon I will get a job, but this misconception should stop because it hampers our career development." RI3 said. 
The research results of this study have shown that gender bias and sexual harassment are still found in the mining sector, caused by or based on cultural background, historical and society-based disadvantaged women. Based on the fact that females or women are paramount in their families' wellbeing whereby the increase of their income allows them to answer basic needs of consumption and survival expenditures of their families Nader (2008), gender bias should be eradicated significantly in all societies. Gender bias still happens when a woman goes to apply for a job in a mining company and gets rejected not because she cannot handle to work there but only because she is a female candidate and historically cannot work in a mine because this job is only for men (Mashiane, 2009; Kilu et al., 2016; Kilu, 2017; Weldegiorgis, Lawson and Verbrugge, 2018; Brands and Fernandez-Mateo, 2017).

From one of the informant's answer, gender bias affects some women's careers as she mentioned that she was seen as someone who could not perform the job even though she studied Engineering, and that happens to other females, which turns them into being continuously unemployed and socially excluded because of not being productive despite the fact that they have taken their study. This needs to be changed.

"We want to have such a career guidance course in universities so that female will be aware of gender bias issues that are waiting for them at workplaces before finishing their studies so that they will be ready to tackle them." RI7 suggested.

Many careers are discerned as gendered, where "men and women are seen as distinctly different distinguished in accomplishing a given task well". Generally, "even recruitment choices are partly influenced with whether or not the work in question is deemed more appropriate for men or females", thereby resulting in gender-based discrimination in recruitment process, and this is what happens in mining companies. If females have a career guidance or formation during their school or education, things would be different especially the way they react or fight against gender bias in terms of their career development.

"Yeah, Gender Bias happens. I sometimes see job adverts, and there is a point mentioning that they need only males or only females. Why is that? They should let everyone compete and fail or win. Gender bias is not only about females but also about males. Look at these marketing companies. Most of them, when they are hiring, call for females to be on their advertisement boards. But why? Is it because females can attract customers more than males? That's why when it comes to other kinds of jobs women will be ignored as it happens in mining companies. This should change." BI10 said.

Gender bias at workplaces should be eradicated not only for women but also for men. Any data offered to the recruitment team that takes into account the applicant's gender is understood to affect the choice of suitability of this postulant for a certain position. The significance of generalizations about employment and eligibility depending on the gender of the candidate is one of the procedures highlighted by some researchers concerning gender bias in recruitment whereby some recruiters appear to have gender biased traits, fairness of the recruitment, promotion, and empowerment. Women in this industry have long been a challenge, and therefore for human resource managers or recruiters in mining companies, during the formation or preparation of job description and job specification, the authors of this study suggest that gender issue should be taken into account so that there will be no gender bias on board.

"We got to make sure that managers in the mining sector overcome superior gender bias and are inspired to assign difficult work equally to their male and female subordinates. Ladies ought to even be made attuned to their tendency to take on less difficult tasks and also to the adverse consequences this has had on their careers. People ought to even be conscious of how they bring up their kids. Every son and daughter ought to be inspired to step up for difficult tasks." RI13 recommended.

Challenges give chances to realize the competence, which will result in the improvement of a wide scope of aptitudes, capacities, some knowledge, information, and qualities that contribute towards viable administration abilities, and thus, career achievement. The results or impacts of the individual representatives can be numerous and consequential. Under certain circumstances, an irritated female is having the possibility for advancing her career if she does not surrender to the sexual requests of somebody in power. In a different circumstance, the unwanted sexual urges from workmates create the threatening and horrendous working conditions, forcing her to leave work, although perhaps, more offensive behaviour experienced by the worker are able to make her figure out how to defend herself and deal with the provocation effectively. Moreover, occasionally, the 
worker is so mentally damaged by the provocation that she endures solemnly passionate and physical results and frequently, is incapable to play out her daily activities appropriately. As stated by one informant below:

"I work as a fieldworker in one NGO here in Burundi. I was a victim of sexual harassment several times by my head of department who was always asking me to sleep with him and intimidating me of being fired if I refuse. Yeah, I refused and decided not to expose him because of fear of being fired afterward. You know that getting a job in a mining company as a female is not something easy. Even though he didn't achieve his objective, I ended up being excluded from my fieldwork which I used to do before he started asking me. I am even afraid that one day I might be fired for nothing." BI5 explained.

When sexual harassment happens in the workplace, not only the victim suffers but also everyone who knows about this issue will be negatively impacted. It may be customers, peer workers, or even the victim's family. "Any individuals having information on this sexual harassment issue will lose the credibility of the organization or the harasser and after all, it will affect the whole company as well as the society." Researchers have found that sexual harassment at the workplace among employees is significant and endangers job satisfaction and negatively impacts the whole workforce. It is also mentioned that most determinates of sexual harassment are being single, working in open units, and having fewer years of experience. This was confirmed by the informants who said that she had been a victim of sexual harassment and she accepted that to happen because she did not have much experience and she was afraid of being fired. In return after having an affair with her boss, she ended up being promoted.

"I am 28 years old; I work as a site engineer in one mining company. Before this, I was just a casual worker in the same company. That time, my boss approached me and when I thought about his words, I found out that if I refused, I would be fired. And I knew that getting a job related to mining engineering as a female won't be easy. He promised me a promotion and then I accepted. Now we are talking, I am a site engineer. But I don't recommend my fellow women or girls to do the same because it is not safe. "BI4 sated.

"Some females fail to resist to sexual harassment for fear of losing their jobs or positions, and in the case of the mining industry, this is caused by the aforementioned misconceptions that females cannot work in mining." This makes this condition persistent and difficult to deal with. To protect those who fear, it is obvious that many females have experienced sexual harassment at the workplace, and this circumstance has negative consequences for the victim along with the organization. Thus, it is suggested that "an appropriate framework for managing inappropriate behaviour cases ought to be introduced at the work environment to keep ladies from being casualties because sexual harassment is pervasive in labour markets".

\section{DISCUSSION}

Gender bias as well as sexual harassment are stumbling blocks to the career development of females all over the world. This is because discrimination is defined as treating somebody differently from others based on their membership in a social group, and it finally creates or boosts social exclusion to females who experience it at work or in the community (Verniers and Vala, 2018). Meanwhile harassment is defined as verbal or physical hurting someone intentionally to make him or her to suffer in one way or another to take advantage of them in personal interest (Piñeiro and Kitada, 2020).

The world is working under technology pressure nowadays, and digital transformation has become a high priority on the leadership agenda of many organizations. Security devices at workplaces are also profusely being invented Nadeem et al. (2018), which could be useful in tackling all sorts of gender-based violence through digital surveillance in organizations and other technology-based methods of protecting females at workplaces and outside. Gender balance and promotion should be promoted in order to remove obstacles that prevent women from entering the mining sector in the first place as well as from gaining positions at all levels, from the mine site to managerial and board levels as well as in related input and output sectors such as investment, trading, equipment and services. This includes applying gender equity principles through positive discrimination and promoting opportunities for women.

The world of work without gender inequality could be seen or considered as a small paradise for both male and female workers. Understanding this vision requires passion and preparation for 
social change. Gender sensitive indicators and different estimates of progress are the basis for the case structure for paying attention to gender (in)equality, empowering having better plans and activities, and considering organizations responsible for their responsibilities on gender. Gender equality will be empowered if Human Capital Theory is effectively applied, or specifically, gender bias will not have space in the mining sector and in the course of females' career management development processes. People with challenging professional adventures will, in general, be seen as progressively proficient, more eager to attempt a new challenge, and more goal-oriented to achieve higher-level positions. Over the whole career life, the contrast of sexual orientation in self-assessed career desire can be appraised as indicators of contrasts in the improvement of male and female vocation profiles.

Our society and their social norms attribute the distinguishing characteristics of women and men, supporting their biological sex. For instance, women are light, emotional, sensitive or hysteric while men are authoritative, magnetic, wealthy, and powerful (Dubbelt, Rispens and Demerouti, 2016). These characteristics are the product of education and learning, and they will develop a hindrance to future career development and management particularly for females who become a target of social long-lasting unemployment especially for those who study mining engineering (Kilu et al., 2016). One scientist said that our brains develop through interactions with the outside world (parents, families, schools, etc.) as a result of learning and education (Hassi and Rekonen, 2018).

On the other hand, sexual harassment of women which is even a complex and multifaceted phenomenon (Nielsen et al., 2017), continues to grow rapidly. It is defined as a bunch of genderbased violence practices (Villegas, 2019), which lead to sexual requests or forced sexual relationships. Many studies have shown and affirmed that women's sexual abuse or harassment at workplaces is tremendously increasing in many areas of the world especially where the unemployment rate is higher. This condition can cause very severe consequences for both parties of the person being harassed and other female co-workers who experience it as a third party or as a second party. (Raj et al., 2020) reported that women who are mostly encountering lewd behaviour early in their career stay at more serious hazards for this maltreatment long after their outstanding accomplishments. In the mining industry, even though very few numbers of females get employed, they also face sexual harassment afterward during their daily working lives.

Some research show that women are, indeed, less inclined to take up challenging tasks than men because they are more likely to avoid failure, but this should not be the issue to make gender bias perceived as if there is no impact. We are in an exceedingly scenario where ladies could avoid being denied in vital organic process opportunities, which successively hamper their possibilities of promotion and career advancement and management.

Women can perform almost every work if they are given a chance, time, freedom, and space to develop their careers. Even in politics, women can excel as men do when it comes to policy setup and implementation. All over the world, there is an increasing quantity of female labour, which then raises the idea on whether or not a better level of women's illustration in parliament results in a distinct sort of parliamentary politics. For accelerating females' career development and management in the mining industry, Human Capital Theory can be used as a guidance about the outcomes of the development of females' careers. The initial human capital attained through formal schooling and resultant human capital obtained informally on the work are found to be enhanced within the production of performance and career success. There is an oversized body of literature on the link between firm-specific human capital and wages, the relative worth of firm-specific human capital has been seldom studied within the context of career success which it's additionally helpful to broaden the breadth of human capital at intervals the firm that while not, inform to the importance of firm-specific human capital for career success.

It should be noted that sexual orientation-based and politically-inspired outrages have a growing negative effect on women. For examples, physical brutality, the real damage of homicide/endeavoured murder, physical or enthusiastic attack, injury, and the battery have negatively affected women (Zengenene and Susanti, 2019), which hinders women career management and development journey. Gender-stereotype, where women are positioned in jobs concerning the domestic sphere still occur as seen in the mining industry. There are three sorts of gender bias in work, namely "prove-it-again bias", "tightrope bias" and also the "maternal wall"(Plickert and Sterling, 2017). This means that women need to appear highly skilled and 
demonstrate technical art in the slightest amount of time to receive equivalent respect as male engineers. Women should also operate within an acceptable range of behaviour that is neither too female nor too masculine to avoid being labelled "emotional", and also the ideal employees are often available for work for which mothers do not or should not remain committed to their careers.

Based on the research findings, some recommendations are provided to address the difficulty of gender bias and sexual harassment in the mining industry. In some countries, women are not allowed to drive, including to vote; this might be a reason or cause of social exclusion. This research found that gender biased recruitment, work assignments, misconceptions, culture and societal norms still exist in the mining industry. All of them and many others are driving factors for gender bias, but we have also seen many ways how to support females to escape this issue of gender bias which most of the time hinders their career development. Society needs to improve the understanding of gender, support female workers, and motivate young women to be active in all employment sectors especially in the mining sector.

\section{CONCLUSION}

Based on the research results obtained from the views and ideas of informants as well as previous literature, gender bias as one of the ways of discrimination and sexual harassment and as one of the acts of mistreatment of women in the mining sector hinders women's career management and development process as well as their work safety. Women in mining industry from Rwanda and Burundi have suffered from gender bias and sexual harassment at work or during the process of seeking jobs in the mining industry, and it hampers their career development process, not to forget their safety at work.

In conclusion, we cannot neglect to say that although this research produced findings that assent that gender bias and sexual harassment can significantly hamper the career development and females' work safety in mining industry, in addition to the sustainable development of the mining industry, the research was carried out with female informants only, which can limit the significant diversity of data and information. Therefore, future researchers should conduct more in-depth research with both male and female informants and use other methodologies especially gender sensitive approaches and additional data and information about the issue of gender bias towards career development.

\section{ACKNOWLEDGEMENTS}

The researchers would like to express sincere gratitude to the informants who have helped the completion of this research by willing to participate in the interviews even though it was not easy for them to answer confidential questions. The researchers are also glad to express their deepest gratitude to the staff of Graduate School (Sekolah Pascasarjana) who are always willing to help students in their research career. Without them, this research paper would not have been successfully completed.

\section{REFERENCES}

Abrahamsson, L. et al. (2014) Mining and Sustainable Development: Gender, Diversity and Work Conditions in Mining.Sweden: Luleå University of Technology.

Botha, D. (2016) 'Women in Mining: an Assessment of Workplace Relations Struggles', Journal of Social Sciences, 46(3), pp. 251-263.

Botha, D. and Cronjé, F. (2014) 'Workplace Opportunities for Women Employed in Core Mining Activities', Mediterranean Journal of Social Sciences, 5(23), pp. 1914-1926.

Brands, R. A. and Fernandez-Mateo, I. (2017) 'Leaning Out: How Negative Recruitment Experiences Shape Women's Decisions to Compete for Executive Roles', Administrative Science Quarterly, 62(3), pp. 405-442.

Cao, J. and Thomas, D. (2013) When Developing a Career Path, What are the Key Elements to Include?, Cornell University Library.

Dubbelt, L., Rispens, S. and Demerouti, E. (2016) 'Gender Discrimination and Job Characteristics', Career Development International, 21(3), pp. 230-245.

Erlingsson, C. and Brysiewicz, P. (2017) 'A Handson Guide to Doing Content Analysis', African Journal of Emergency Medicine, 7(3), pp. 93-99.

Fahriany, Alek and Wekke, I. S. (2018) 'Gender Representation in English Textbooks for Islamic Junior High School Students', Kafa'ah Journal, 8(2), pp. 149-167. 
Fernandez-Stark, K., Coutu, V. and Bamber, P. (2019) Industry 4. 0 in Developing Countries: The Mine of the Future and the Role of Women. Durham: Duke University Global Value Chains.

Hassi, L. and Rekonen, S. (2018) 'How Individual Characteristics Promote Experimentation in Innovation', International Journal of Innovation Management (IJIM), 22(4), pp. 1-30.

Jáuregui, K. and Olivos, M. (2018) 'The Career Advancement Challenge Faced by Female Executives in Peruvian Organisations', Brazilian Administration Review, 15(4), pp. 1-20.

Jenkins, K. (2014) 'Women, Mining and Development: An Emerging Research Agenda', The Extractive Industries and Society, 1(2), pp. 329-339.

Kilu, R. H. et al. (2016) 'Investigating the NonGendered Recruitment Characteristics of Mining Firms in Ghana: The Role of Sociocultural, Psychosocial and Organizational Design Factors', Business and Management Quarterly Review, 7(3/4), pp. 38-51.

Kilu, R. H. (2017) Shifting Gender Dynamics in Multinational Ghanaian Mine Jobs: Narratives on Organizational and Sociocultural Barriers. Doctoral Thesis. Sweden: Department of Business Administration, Technology and Social Sciences, Lulea University of Technology.

Kurniawan, Y. et al. (2018) 'Gender Bias in the Workplace: Should Women be Marginalized in Engineering Job?', in IOP Conference Series: Materials Science and Engineering, pp. 1-5.

Larsson, G. and Alvinius, A. (2019) 'Comparison within Gender and between Female and Male Leaders in Female-Dominated, Male-Dominated and Mixed-Gender Work Environments', Journal of Gender Studies. Routledge, 29(7), pp. 739750.

Mankhi, A. H. (2020) 'Black Female Masculinity in Toni Morrison's Sula', Utopia y Praxis Latinoamericana, 25(Esp1), pp. 32-39.

Mashiane, B. R. (2009) Transformational Barriers Against Women's Advancement In South African Platinum Mining Companies. Dissertation. Potchefstroom: North West University.

Nadeem, A. et al. (2018) 'Editorial: Digital Transformation \& Digital Business Strategy in Electronic Commerce - The Role of Organizational Capabilities', Journal of Theoretical and Applied Electronic Commerce Research, 13(2), pp. I-VIII.

Nader, Y. F. (2008) 'Microcredit and the SocioEconomic Wellbeing of Women and Their
Families in Cairo', Journal of Socio-Economics, 37(2), pp. 644-656.

Naderifar, M., Goli, H. and Ghaljaie, F. (2017) 'Snowball Sampling: A Purposeful Method of Sampling in Qualitative Research', Strides in Development of Medical Education, 14(3), pp. 1-4.

Nielsen, M. B. D. et al. (2017) 'Sexual Harassment in Care Work - Dilemmas and Consequences: A Qualitative Investigation', International Journal of Nursing Studies, 70(May), pp. 122-130.

Nurmala, I., Astutik, F. N. and Devi, Y. P. (2020) 'Surrounding the Reason for Women to Continue the Tradition of Child Marriage', Utopia y Praxis Latinoamericana, 25(Extra2), pp. 24-32.

Pimpa, N. (2019) 'How Mining Companies Promote Gender Equality through Sustainable Development?', Cogent Business and Management, 6(1), pp. 1-11.

Piñeiro, L. C. and Kitada, M. (2020) 'Sexual Harassment and Women Seafarers: The Role of Laws and Policies to Ensure Occupational Safety \& Health', Marine Policy, 117(July), pp. 1-9.

Plickert, G. and Sterling, J. (2017) 'Gender Still Matters: Effects of Workplace Discrimination on Employment Schedules of Young Professionals', Laws, 6(4), pp. 28-50.

Pugliese, F. (2020) 'Mining Companies and Gender(ed) Policies: The Women of the Congolese Copperbelt, Past and Present', Extractive Industries and Society, 8(2), pp. 1-8.

Raj, A. et al. (2020) 'Effects of Sexual Harassment on Advancement of Women in Academic Medicine: A Multi-Institutional Longitudinal Study', EClinicalMedicine, 20(March), pp. 1-8.

Schulz, D. J. and Enslin, C. (2014) 'The Female Executive's Perspective on Career Planning and Advancement in Organizations: Experiences With Cascading Gender Bias, the Double-Bind, and Unwritten Rules to Advancement', $S A G E$ Journal, 4(4), pp. 1-9.

Verniers, C. and Vala, J. (2018) 'Justifying Gender Discrimination in the Workplace: The Mediating Role of Motherhood Myths', PLoS ONE, 13(1), pp. 1-23.

Villegas, P. E. (2019) “"I Made Myself Small Like a Cat and Ran Away": Workplace Sexual Harassment, Precarious Immigration Status and Legal Violence', Journal of Gender Studies, 28(6), pp. 674-686.

Weldegiorgis, F., Lawson, L. and Verbrugge, H. (2018) Women in Artisanal and Mining: 
Challenges and Opportunities for Greater Participation. Canada: The International Institute for Sustainable Development.

World Health Organization (2009) Promoting Gender Equality to Prevent Violence Against Women. Series of. Geneva: World Health Organization.
Zengenene, M. and Susanti, E. (2019) 'Violence Against Women and Girls in Harare, Zimbabwe', Journal of International Women's Studies, 20(9), pp. 83-93. 